\title{
Long-Term Successful Treatment of Indolent Systemic Mastocytosis With Omalizumab
}

\author{
Maj Samuel L. Weiss, USAF, MC; Maj John B. Hyman, USAF, MC; Maj Geoffrey S. Carlson, USAF, MC; \\ and Col Christopher A. Coop, USAF, MC
}

This case study suggests that omalizumab may help prevent anaphylaxis and reduce disease burden associated with systemic mastocytosis, but further studies and formal clinical trials are needed to confirm these findings.

\begin{abstract}
Samuel Weiss is an Allergy/Immunology Fellow, and John Hyman is a Pediatrician, both at San Antonio Uniformed Services Health Education Consortium in Fort Sam Houston, Texas. Geoffrey Carlson is an Allergist, and Christopher Coop is the Program Director of the Allergy/Immunology Fellowship, both at Wilford Hall Ambulatory Surgical Center, Lackland Air Force Base in Texas.

Correspondence: Samuel Weiss

(samuellweiss@gmail.com)
\end{abstract}

Fed Pract. 2021;38(1):44-48. doi:10.12788/fp.0081
$\mathrm{M}$ astocytosis is a rare disease that causes allergic and anaphylactic symptoms due to chronic or episodic, excessive mast cell degranulation as well as mast cell infiltration of the skin or other organs. ${ }^{1}$ Mast cells aid in innate immunity by generation of a vasodilatory and inflammatory response and are significant contributors to allergic reactions. Cutaneous mastocytosis is defined by isolated skin involvement. Systemic mastocytosis (SM) is characterized by mast cell infiltration of extracutaneous organs, most often bone marrow. ${ }^{2}$

\section{BACKGROUND}

SM is divided into distinct subtypes (Table 1). Nonadvanced SM subtypes include indolent SM and smoldering SM. These are the most common forms and tend to have more slowly progressing courses without evidence of organ tissue dysfunction, a myelodysplastic syndrome, or of a myeloproliferative disorder. $^{3}$ Advanced SM is less common and is associated with organ tissue dysfunction. It also may be associated with myeloproliferative, myelodysplastic, or lymphoproliferative hematologic neoplasms, and subtypes include aggressive SM, SM with an associated hematologic neoplasm, and mast cell leukemia (Table 2). ${ }^{4}$

Treatment options approved by the US Food and Drug Administration (FDA) for advanced SM include disease-altering medications, such as tyrosine kinase inhibitors (eg, imatinib), but the approved treatment options for nonadvanced SM are generally aimed at managing only symptoms (Table 3 ). Although not approved by the FDA for the treatment of SM, omalizumab may aid in the prevention of anaphylaxis, the reduction of disease burden, and the improvement in quality of life for patients with SM. ${ }^{5}$ Omalizumab is a humanized monoclonal antibody against the Fc portion of immunoglobulin E (IgE). It is approved by the FDA for treatment of asthma as well as chronic idiopathic urticaria. ${ }^{6}$

\section{CASE PRESENTATION}

A 32-year-old female initially presented to Womack Army Medical Center at Fort Bragg, North Carolina, for evaluation due to recurrent episodes of anaphylaxis occurring 1 to 2 times per month as well as chronic skin rashes that progressed over the previous 5 years (Figure). She initially was diagnosed with idiopathic anaphylaxis and subsequently had multiple emergency department (ED) and clinic visits for vasovagal syncope, unexplained allergic reactions, dizziness, giddiness, and shortness of breath. More recently, she was diagnosed with idiopathic urticaria.

The patient reported at least 12 episodes in the previous year involving facial flushing that proceeded inferiorly, chest tightness, shortness of breath, labored breathing, crampy abdominal pain, and nausea without urticaria or significant pruritus. These bouts often were accompanied by mild facial angioedema, acute sinus pressure, vomiting, tachycardia, and lightheadedness. She reported experiencing brief losses of consciousness with at least 4 of these episodes. Home and ED blood pressure measurements revealed hypotension on several 
occasions with systolic readings in the 80 s. She also developed nonpruritic freckles on her upper chest initially with subsequent increase in number and spread to involve her entire trunk, proximal extremities, and eventually distal extremities.

The patient had received intramuscular epinephrine several times, which led to rapid resolution of her symptoms. Intensive care unit admission for observation overnight was deemed necessary following one of her first episodes, but she did not require intubation or vasopressor support. Eventually, she began treating most episodes at home with diphenhydramine, ranitidine, and occasionally an epinephrine auto-injector, only presenting to the ED for severe dyspnea or loss of consciousness. Some episodes awoke her from sleeping but no triggers were identified (eg, foods, alcohol, supplements, medications, insect stings, latex exposure, exercise, strong emotions, or menstrual cycle).

Examination revealed hyperpigmented macules and papules scattered on the trunk and extremities, with a positive Darier sign. Punch biopsy of one of the macules revealed focal basal cell hyperpigmentation and sheets of benign-appearing mast cells in the superficial dermis, highlighted by CD117 immunohistochemical stain. A serum tryptase level was obtained and found to be significantly elevated $(134 \mathrm{mcg} / \mathrm{L})$. The patient was diagnosed with maculopapular cutaneous mastocytosis (urticaria pigmentosa).

A bone marrow biopsy revealed multiple prominent infiltrates of monomorphic, spindled, CD117-positive, CD2-positive, and CD25-positive mast cells arranged interstitially and paratrabecularly, with associated reticulin fibrosis. Indolent SM was diagnosed according to the World Health Organization classification system with multifocal, dense aggregates of mast cells (> 25\%) in the bone marrow and with persistently elevated serum tryptase levels (134, 134, 151, and $159 \mathrm{ng} / \mathrm{mL}$ ) without laboratory evidence of an associated clonal myeloid disorder or findings consistent with infiltrating bone lesions on full body magnetic resonance imaging scan. ${ }^{4}$

Despite maximal antihistamine and antileukotriene therapy with ranitidine (150 mg twice daily), cetirizine (10 mg twice daily), montelukast (10 mg daily), and cromolyn sodium (200 mg daily), the pa-

\section{FIGURE Diffuse Flushing During Acute Episodes of Anaphylaxis Related to Systemic Mastocytosis}

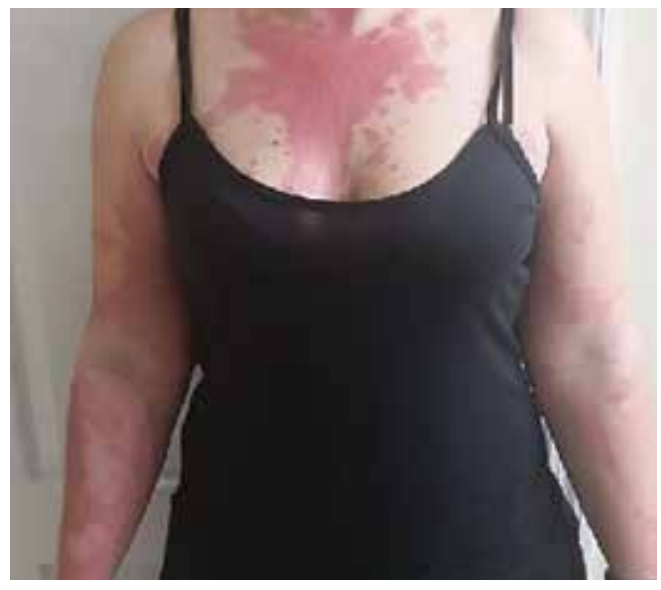

TABLE 1 Mastocytosis Classifications ${ }^{1}$

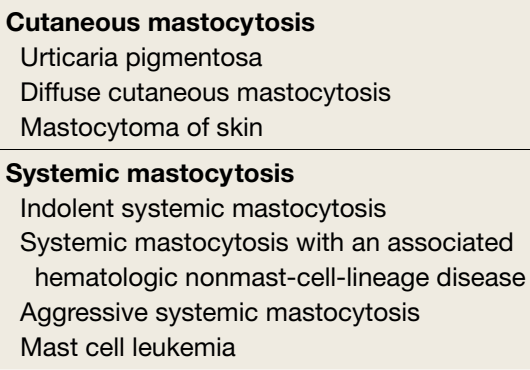

tient continued to experience recurrent episodes of anaphylaxis requiring subcutaneous epinephrine and systemic corticosteroids. In May 2016, the patient began a trial of off-label therapy with omalizumab injections (300 mg subcutaneous every 4 weeks). She has continued on therapy for more than 4 years and experienced only 1 anaphylactic episode. She also has had significant improvement in cutaneous symptoms.

\section{DISCUSSION}

Mast cell overactivation and degranulation in mastocytosis is largely driven by the $\mathrm{IgE}$ antibody, which plays a significant role in atopic conditions, immediate hypersensitivity reactions, and anaphylaxis, as well as in the immunologic response to parasitic infections. The severity of atopic disease seems to be associated with serum IgE levels in many patients. ${ }^{7}$ IgE binding to surface receptors on mast cells and eosinophils prompts the release of toxic mediators, incites inflammation, and induces allergic symptoms. ${ }^{8}$ Activation of 
TABLE 2 Clinical Manifestations of Cutaneous and Systemic Mastocytosis ${ }^{19}$

\begin{tabular}{|c|c|c|}
\hline Organ Systems & $\begin{array}{l}\text { Symptoms due to Acute and/or } \\
\text { Chronic Mast Cell-Mediator Release }\end{array}$ & $\begin{array}{l}\text { Symptoms, Physical Findings, and Abnormalities of } \\
\text { Routine Laboratories due to Organ Infiltration }\end{array}$ \\
\hline Skin & Flushing, pruritus & $\begin{array}{l}\text { Multiple: Urticaria pigmentosa, plaquelike or nodular lesions, diffuse skin } \\
\text { involvement, bullous eruptions, isolated mastocytoma, or telangiectasias }\end{array}$ \\
\hline $\begin{array}{l}\text { Gastrointestinal } \\
\text { tract }\end{array}$ & $\begin{array}{l}\text { Nausea, bloating, chronic diarrhea, } \\
\text { hyperacidity, gastroduodenal ulcer } \\
\text { disease, chronic abdominal pain, } \\
\text { vomiting }\end{array}$ & $\begin{array}{l}\text { Stomach and duodenal infiltration: Gastroduodenal ulcers (possibly, although } \\
\text { more clearly related to mediator release), steatorrhea, malabsorption } \\
\text { Liver infiltration: Elevated transaminases, portal hypertension, and ascites (only } \\
\text { in advanced forms of the disease) }\end{array}$ \\
\hline Musculoskeletal $^{a}$ & $\begin{array}{l}\text { Adults: Fibromyalgia-like diffuse } \\
\text { musculoskeletal pain, pain in long bones, } \\
\text { osteoporosis, osteopenia, pathologic } \\
\text { fractures }\end{array}$ & $\begin{array}{l}\text { In mast cell sarcoma of the bone (rare), local symptoms (eg, pain, deformity, } \\
\text { pathologic fracture) occur at the involved site }\end{array}$ \\
\hline Cardiovascular & $\begin{array}{l}\text { Adults: Episodes of vasodilation, } \\
\text { tachycardia, hypotension, collapse } \\
\text { Infants: Apneic spells, cyanosis }\end{array}$ & \\
\hline $\begin{array}{l}\text { Hematologic } \\
\text { (lymph nodes, } \\
\text { spleen, bone } \\
\text { marrow) }\end{array}$ & & $\begin{array}{l}\text { Lymph nodes and spleen: Lymphadenopathy, splenomegaly (with } \\
\text { hematologic findings of hypersplenism: nonimmune hemolytic anemia) } \\
\text { Bone marrow: Anemia (mild-to-moderate, in approximately 50\%), } \\
\text { thrombocytopenia (usually asymptomatic), eosinophilia (approximately 25\%), } \\
\text { myeloproliferative or myelodysplastic findings, fibrosis }\end{array}$ \\
\hline $\begin{array}{l}\text { Neurologic, } \\
\text { psychiatric }\end{array}$ & $\begin{array}{l}\text { Adults: Anxiety, depression, } \\
\text { headache, mood changes, inability } \\
\text { to concentrate, hypersomnolence, } \\
\text { irritability, "mixed organic brain } \\
\text { syndrome" } \\
\text { Children: Aggressive behavior }\end{array}$ & \\
\hline Systemic ${ }^{a}$ & Adults: Fatigue, cachexia & \\
\hline
\end{tabular}

aRare in children. Signs and symptoms of both acute and chronic release of mast cell mediators are seen in patients with cutaneous and systemic forms of mastocytosis. Episodic symptoms tend to occur in patterns that are characteristic for a given patient, but not all patients demonstrate all of the signs and symptoms described in the table. In patients with cutaneous mastocytosis, mast cells infiltrate the skin. In patients with systemic mastocytosis, mast cells may infiltrate the skin, gastrointestinal tract and liver, lymph nodes, spleen, and bone marrow.

mast cells is classically elicited by IgE binding to the high-affinity Fce RI receptor, the expression of which correlates with IgE levels. ${ }^{9}$

The anti-IgE, recombinant, humanized immunoglobulin G monoclonal antibody, omalizumab, decreases mastocytic and eosinophilic symptoms by binding and inhibiting IgE. This diminishes free IgE levels, inhibits IgE binding to the Fce RI receptor, and affects downregulation of this high-affinity receptor on mast cells and basophils. ${ }^{6}$ Omalizumab is currently FDA approved only for the treatment of moderate-to-severe, persistent, allergic asthma that is not controlled by inhaled corticosteroids in patients aged $\geq 6$ years, and for chronic idiopathic urticaria not controlled by $\mathrm{Hl}$ antihistamine therapy in patients aged $\geq 12$ years. ${ }^{10}$ However, it stands to reason that this therapy also should be effective in the treatment of other poorly controlled atopic conditions, especially mastocytosis, the symptoms of which are driven by excessive mast cell degranulation and tissue infiltration.
As early as 2007, preliminary data showed that treatment with omalizumab could decrease the frequency of episodes of anaphylaxis. ${ }^{11}$ A National Institutes of Health case report followed 2 patients, one for 5 months and the other for 24 months. Both patients experienced a decrease in frequency of anaphylaxis following initiation of omalizumab. In 2010, a second case report described the treatment of an Australian patient with recurrent idiopathic anaphylaxis also diagnosed with SM. After initiation of treatment with omalizumab, she, too, experienced decreased frequency of episodes of anaphylaxis over 14 months. ${ }^{12}$ A review of patients treated at the Mastocytosis Centre Odense University Hospital in Denmark was published in 2017. Of 13 patients with SM treated with omalizumab, 5 experienced what was considered a complete response to the medication, with 3 each experiencing major and partial responses. $^{5}$ The median treatment time in these patients was 27 months. Each of these cases 
TABLE 3 Mastocytosis Treatments 20

\begin{tabular}{|c|c|c|c|c|}
\hline $\begin{array}{l}\text { Category of Cutaneous } \\
\text { Mastocytosis Symptoms }\end{array}$ & Subcategory & First-Line Therapy & Other Therapies & Prevention \\
\hline \multirow[t]{3}{*}{ Skin lesions } & MPCM/UP & $\begin{array}{l}\text { Short-term therapy with } \\
\text { topical corticosteroids; } \\
\text { treatment is not necessary } \\
\text { in the majority of cases }\end{array}$ & $\begin{array}{l}\text { Topical corticosteroids UVA, } \\
\text { narrow-band UVB, PUVA, } \\
\text { pimecrolimus }\end{array}$ & $\begin{array}{l}\text { Identification and avoid- } \\
\text { ance of triggers, factors, } \\
\text { including the patients with } \\
\text { IgE-mediated allergy }\end{array}$ \\
\hline & DCM & $\begin{array}{l}\text { Short-term therapy with } \\
\text { topical and oral } \\
\text { corticosteroids }\end{array}$ & UVA narrow-band UVB, PUVA & \\
\hline & Mastocytoma & $\begin{array}{l}\text { Without treatment of } \\
\text { topical corticosteroids }\end{array}$ & $\begin{array}{l}\text { Surgical excision, injection with } \\
\text { crystalline steroid solutions, } \\
\text { pimecrolimus }\end{array}$ & \\
\hline \multirow[t]{4}{*}{$\begin{array}{l}\text { Mast cell mediator-related } \\
\text { symptoms }\end{array}$} & $\begin{array}{l}\text { Tachycardia, } \\
\text { hypertension, } \\
\text { headache }\end{array}$ & $\begin{array}{l}\text { Second-generation } \\
\text { H1-antihistamines; If } \\
\text { symptoms persist, increase } \\
\text { the dose up to } 4 \text { times }\end{array}$ & $\begin{array}{l}\text { Adrenaline, } \mathrm{H} 2 \text {-antihistamines, } \\
\text { oral glucocorticoids }\end{array}$ & \\
\hline & $\begin{array}{l}\text { Pruritus flushing, } \\
\text { skin wheals }\end{array}$ & & $\begin{array}{l}\text { H2-antihistamines, leukot- } \\
\text { riene antagonist, disodium } \\
\text { cromoglycate NSAID, topical } \\
\text { glucocorticoids, PUVA, UVA, } \\
\text { narrow-band UVB }\end{array}$ & \\
\hline & $\begin{array}{l}\text { Abdominal pain, } \\
\text { nausea, diarrhea, } \\
\text { duodenal ulcers }\end{array}$ & & $\begin{array}{l}\text { H2-antihistamines, } \\
\text { proton pump inhibitors, oral } \\
\text { disodium cromoglycate, } \\
\text { oral glucocorticoids }\end{array}$ & \\
\hline & Anaphylaxis & $\begin{array}{l}\text { Adrenaline (epinephrine) } \\
\text { autoinjector, } \mathrm{H} 1, \mathrm{H} 2 \text { antihis- } \\
\text { tamines, glucocorticoids }\end{array}$ & $\begin{array}{l}\text { Omalizumab in recurrent } \\
\text { anaphylaxis, SIT in } \\
\text { hymenoptera, hypersensitivity }\end{array}$ & \\
\hline
\end{tabular}

Abbreviations: DCM, diffuse cutaneous mastocytosis; IgE, immunoglobulin E; MPCM, maculopapular cutaneous mastocytoma; NSAID, nonsteroidal anti-inflammatory drugs; PUVA, UVA plus psoralen; SIT, specific immunotherapy, UP, urticaria pigmentosa; UVA, ultraviolet A; UVB, ultraviolet B.

showed significant promise in the use of omalizumab to treat SM, informing the decision to attempt this treatment in our patient.

The potential positive effects of omalizumab in reducing symptom severity in patients with SM was further supported by a 2017 meta-analysis. This review included several individual case reports noting that omalizumab could decrease frequency of pulmonary and gastrointestinal manifestations of SM. ${ }^{13}$ A small randomized control trial of omalizumab for treatment of mild symptoms of SM found improvement in disease severity, although neither primary nor secondary endpoints reached statistical significance. $^{14}$

This case demonstrates a substantial, long-term, clinical benefit and quality of life improvement with omalizumab therapy in a patient with indolent SM that was not adequately controlled by conventional therapies. This is evidenced by an impressive decline in the frequency of mastocytic ana- phylactic episodes as well as diminished patient-endorsed cutaneous symptoms.

This case provides further evidence of the efficacy of this therapy in diminishing disease burden for patients with SM who are otherwise limited to treatments aimed at transient symptomatic relief without significant alteration of the underlying cause of symptoms. At the time this article was written, our patient had now 52 months of continuous treatment without any adverse reactions noted, suggesting the treatment's long-term efficacy. It also adds to a small but growing body of literature that supports the use of anti-IgE therapy as a treatment option for improved management of this distressing, life-altering illness. Even in the time that our patient has been receiving omalizumab for SM, another small case series of 2 patients has been published showing sustained treatment effect at 12 years of therapy. ${ }^{15}$ This adds further insight that omalizumab can offer long-term, safe treatment for this limiting condition. 
Omalizumab therapy is not without risk, but for patients afflicted by unrestrained mastocytic disease, the benefits may outweigh the risks. The most common significant risk with this medication is anaphylaxis, occurring in 1 to 2 per 1,000 patients, usually within 2 hours of an injection. ${ }^{16}$ This may correlate to the underlying degree of atopy in patients receiving omalizumab, and the risk of anaphylaxis is relatively low compared with that of many other biologic medications. ${ }^{17}$ Additionally, early data from initial phases of clinical trials indicated a potentially elevated malignancy risk with omalizumab. However, subsequent pooled analysis of larger numbers of patients has decreased suspicion that a causal relationship exists. ${ }^{18}$

\section{CONCLUSIONS}

Omalizumab has proven value in the treatment of atopic conditions, such as asthma and idiopathic urticaria, for which it has been approved for use by the FDA. Its effectiveness in significantly decreasing free serum IgE levels, and inhibiting IgE activation of mast cells makes it a possible treatment option for patients with SM who are not sufficiently controlled with conventional therapy. The findings in this case suggest that omalizumab may be effective in the prevention of anaphylaxis and in the reduction of disease burden associated with SM. Further studies and formal clinical trials are needed to confirm these findings. Patients should be counseled appropriately concerning the risks, benefits, and off-label status of this treatment option.

\section{Author disclosures}

The authors report no actual or potential conflicts of interest with regard to this article.

\section{Disclaimer}

The opinions expressed herein are those of the authors and do not necessarily reflect those of Federal Practitioner, Frontline Medical Communications Inc., the US Government, or any of its agencies. This article may discuss unlabeled or investigational use of certain drugs. Please review the complete prescribing information for specific drugs or drug combinations-including indications, contraindications, warnings, and adverse effectsbefore administering pharmacologic therapy to patients.

\section{References}

1. Theoharides TC, Valent P, Akin C. Mast cells, mastocytosis, and related disorders. N Engl J Med. 2015;373(2):163172. doi:10.1056/NEJMra1409760

2. Valent P, Sperr WR, Schwartz LB, Horny H-P. Diagnosis and classification of mast cell proliferative disorders: delineation from immunologic diseases and non-mast cell hematopoietic neoplasms. J Allergy Clin Immunol. 2004;114(1):3-11. doi:10.1016/j.jaci.2004.02.045
3. Valent P, Sotlar K, Sperr WR, et al. Refined diagnostic criteria and classification of mast cell leukemia (MCL) and myelomastocytic leukemia (MML): a consensus proposal. Ann Oncol. 2014;25(9):1691-1700. doi:10.1093/annonc/mdu047

4. Valent P, Akin C, Metcalfe DD. Mastocytosis: 2016 updated WHO classification and novel emerging treatment concepts. Blood. 2017;129(11):1420-1427. doi:10.1182/blood-2016-09-731893

5. Broesby-Olsen S, Vestergaard H, Mortz CG, et al. Omalizumab prevents anaphylaxis and improves symptoms in systemic mastocytosis: Efficacy and safety observations. 2018;73(1):230-238. doi:10.1111/all.13237

6. Kaplan AP, Giménez-Arnau AM, Saini SS. Mechanisms of action that contribute to efficacy of omalizumab in chronic spontaneous urticaria. Allergy. 2017;72(4):519-533. doi:10.1111/all.13083

7. Borish L, Chipps B, Deniz Y, Gujrathi S, Zheng B, Dolan C; TENOR Study Group. Total serum lgE levels in a large cohort of patients with severe or difficult-to-treat asthma. Ann Allergy Asthma Immunol. 2005;95(3):247-253. doi:10.1016/S1081-1206(10)61221-5

8. Corry DB, Kheradmand F. Induction and regulation of the IgE response. Nature. 1999;402(suppl 6760):18-23. doi:10.1038/35037014

9. MacGlashan D, McKenzie-White J, Chichester K, et al. In vitro regulation of FcRla expression on human basophils by lgE antibody. Blood. 1998;91(5):1633-1643.

10. XOLAIR [package insert]. East Hanover, NJ: Novartis Pharmaceuticals Corporation. Revised 2019. Accessed November 11, 2020. https://www.accessdata.fda.gov/ drugsatfda_docs/label/2019/103976s5234lbl.pdf

11. Carter MC, Robyn JA, Bressler PB, Walker JC, Shapiro $\mathrm{GC}$, and Metcalfe DD. Omalizumab for the treatment of unprovoked anaphylaxis in patients with systemic mastocytosis. J Allergy Clin Immunol. 2007;119(6):1550-1551. doi:10.1016/j.jaci.2007.03.032

12. Douglass JA, Carroll K, Voskamp A, Bourke P, Wei A, O'Hehir RE. Omalizumab is effective in treating systemic mastocytosis in a nonatopic patient. Allergy. 2010; 65(7):926-927. doi:10.1111/j.1398-9995.2009.02259.x

13. Le M, Miedzybrodzki B, Olynych T, Chapdelaine $H$, Ben-Shoshan M. Natural history and treatment of cutaneous and systemic mastocytosis. Postgrad Med. 2017;129(8):896-901. doi:10.1080/00325481.2017.1364124

14. Distler M, Maul J-T, Steiner T, et al. Efficacy of omalizumab in mastocytosis: allusive indication obtained from a prospective, double-blind, multicenter study (XOLMA Study) [published online ahead of print January 20, 2020]. Dermatology. doi:10.1159/000504842

15. Constantine G, Bressler P, Petroni D, Metcalfe D, Carter M. Twelve-year follow-up of omalizumab for anaphylaxis in 2 patients with systemic mastocytosis. J Allergy Clin Immunol Pract. 2019;7(4)1314-1316. doi:10.1016/j.jaip.2018.07.041

16. Fanta CH. Asthma. N Engl J Med. 2009;360(10):10021014. doi:10.1056/NEJMra0804579

17. Baldo BA. Adverse events to monoclonal antibodies used for cancer therapy: focus on hypersensitivity responses. Oncoimmunology. 2013;2(10):e26333. doi:10.4161/onci.26333

18. Busse W, Buhl R, Fernandez Vidaurre C, et al. Omalizumab and the risk of malignancy: results from a pooled analysis. J Allergy Clin Immunol. 2012;129(4):983-989.e6. doi:10.1016/j.jaci.2012.01.033.

19. Castells M, Akin C. Mastocytosis (cutaneous and systemic): epidemiology, pathogenesis, and clinical manifestations. Accessed December 8, 2020. Updated June 12, 2018. https://www.uptodate.com/contents/mastocytosis -cutaneous-and-systemic-epidemiology-pathogenesis -and-clinical-manifestations

20. Czarny J, Lange M, Lugowska-Umer $\mathrm{H}$, Nowicki R. Cutaneous mastocytosis treatment: strategies, limitations, and perspectives. Postepy Dermatol Alergol. 2018;35(6):541-545. doi:10.5114/ada.2018.77605 